https://helda.helsinki.fi

\title{
Welfare Multiplier of Public Investment
}

\section{Ganelli, Giovanni}

2020

Ganelli , G \& Tervala , J 2020 , ' Welfare Multiplier of Public Investment ' , IMF Economic Review , vol. 68 , no. 2 , pp. 390-420 . https://doi.org/10.1057/s41308-020-00111-7

http://hdl.handle.net/10138/328476

https://doi.org/10.1057/s41308-020-00111-7

Downloaded from Helda, University of Helsinki institutional repository.

This is an electronic reprint of the original article.

This reprint may differ from the original in pagination and typographic detail.

Please cite the original version. 


\title{
Welfare Multiplier of Public Investment
}

\author{
Giovanni Ganelli ${ }^{\mathrm{a}}$ and Juha Tervala ${ }^{\mathrm{b}_{1}}$ \\ anternational Monetary Fund, Washington, DC, United States; e-mail: gganelli@imf.org. \\ Giovanni Ganelli, PhD, is a senior economist at the International Monetary Fund. \\ ${ }^{b}$ University of Helsinki, Finland; e-mail: juha.tervala@helsinki.fi. Juha Tervala, PhD, is the \\ Director of the Bachelor's Programme in Economics at the University of Helsinki.
}

\begin{abstract}
We analyze the welfare multipliers of public spending - the consumption equivalent change in welfare for a one dollar change in public spending - in a DSGE model. The welfare multiplier of public investment depends crucially not only on the productivity (output elasticity) of public capital, as shown by earlier studies, but also on the depreciation rate of public capital and the efficiency of public investment defined as a fraction of public investment spending that translates into the public capital stock. When the key parameter values are set based on the empirical estimates for advanced economies and the output multipliers are consistent with the empirical estimates, the welfare multiplier is positive and sizable. The welfare multiplier is roughly zero when the key parameter values are set to match the features of developing economies. A public infrastructure push in advanced economies makes sense, but developing economies should enhance the efficiency and productivity of public investment.
\end{abstract}

JEL Classification Numbers:E62, F41, H42, H54

Keywords: Public Capital, Public Infrastructure, Public Investment, Public Investment Efficiency, Welfare

\footnotetext{
${ }^{1}$ We are grateful for comment to two anonymous referees, Dimitrios Bermperoglou, Guillaume Claveres, Marlene Isore, Nils Jannsen, In Hwan Jo, Javier Kapsoli, Wolfgang Lechthaler, JungJae Park, Pau Rabanal, Jordan Roulleau-Pasdeloup, Linda Tesar and Juuso Välimäki and the seminar participants at the 5th HenU/INFER Workshop on Applied Macroeconomics, the Costa Rica Global Conference on Business and Finance, the Kiel Institute for the World Economy, the University of Crete, the National University of Singapore, and the INFER Workshop on New Challenges for Fiscal Policy. The views expressed in this paper are those of the authors and should not be attributed to the IMF, its Executive Board, or IMF management.
} 


\section{INTRODUCTION}

The growth and welfare implications of a public investment push is often a topic of discussion in the academic and policy arena. The IMF (2014), for example, argued that in an environment of low government borrowing costs, and given concerns about the impact of infrastructure bottlenecks on potential and near-term growth, a public infrastructure push might be warranted in several countries. Using both cross-country estimates and model simulations, the IMF (2014) concludes that a public investment push raises output in both the short and long term, particularly during periods of economic slack and monetary accommodation.

In Europe, the "Juncker" investment plan launched by the Commission and the European Investment Bank (EIB) aims at increasing public investment by at least 315 billion euros in the medium term. In Japan, a large part of fiscal stimulus under the so-called "second arrow" of Abenomics is earmarked for infrastructure projects. Public investment is often viewed as an important catalyst for economic development. Against this background, it is important to evaluate the consequences of public investment. In the existing literature, this has been done primarily by focusing on the implications for output. For instance, Baxter and King (1993) show that the output effects of public investment depend on the output elasticity of public capital, the responsiveness of output to a change in the stock of public capital.

Rioja (1999) shows that a rise in public investment has a positive effect on welfare, which depends on private consumption and leisure. The higher the output elasticity of public capital, the higher the welfare gain of public investment. Bom and Ligthart (2014) find that the welfare effect of a permanent increase in public investment is positive in the long term if the output elasticity of public capital exceeds the public investment to GDP ratio, which averages roughly 3 percent in OECD countries. Sims and Wolff (2018) find that the welfare multiplier of fiscal policy_defined as the consumption equivalent change in welfare for one dollar change in public spending - is positive. The welfare multiplier, however, becomes negative when the output elasticity of public capital is low.

A key limitation of Baxter and King (1993), Rioja (1999), Bom and Ligthart (2014), and Sims and Wolff (2018) is that the efficiency of public investment, defined as a fraction of public investment spending that translates into the public capital stock, is perfect, so that one dollar of public investment spending translates into one dollar of public capital. Prichett (2000) criticizes the standard version of public capital accumulation where every dollar of public investment spending creates valuable public capital. He finds that the inefficiency of public investment is a serious issue in developing countries. Berg et al. (2019) argue first that a fraction of public investment spending may be wasted as the public investment project costs are higher than they need to be. Second, a fraction of public investment spending may go to corruption. Third, bad project selection means that the public sector may choose projects that produce a low capital services flow. Several empirical studies support the view that there are 
significant inefficiencies in public investment (Caselli 2005, Dabla-Norris et al. 2012, Gupta et al. 2014, IMF 2015). Gupta et al. (2014) estimate that only half of public investment spending translates into public capital in low and middle income countries. The implications of the efficiency of public investment using long-term economic growth models has been analyzed (Berg et al. 2019, Agenor 2010); in macro models its implications for the conduct and transmission of fiscal policy is left unexplored. Dabla-Norris et al. $(2012,240)$ argue that "incorporating PIMI [public investment efficiency] into macro models of development is a notable avenue of future research that is likely to generate new knowledge and inform the policy debate."

The main contribution of this paper is to examine the implications of the efficiency of public investment for the output and welfare multiplier of fiscal policy in a New Keynesian DSGE model. We follow the idea of Prichett (2000) that only a fraction of public investment spending translates into the stock of public capital. The focus on welfare is inspired by Mankiw and Weinzierl (2011), who show that the "bang for the buck" calculations - by how much output increases for one dollar of public spending - are misleading in assessing the welfare effects of fiscal policy, because they ignore the composition of GDP. Similarly, Sims and Wolff (2018) conclude that the output multiplier may be a poor measure of the welfare effects of fiscal policy.

The first main finding is that the welfare multiplier of public investment depends crucially on public investment efficiency, the output elasticity of public capital, and the depreciation rate of public capital. Public investment efficiency determines the extent to which public investment spending increases the public capital stock. The smaller the efficiency of public investment, the smaller the supply-side effect of fiscal policy. Consequently, the welfare multiplier is increasing in public investment efficiency. This finding is new since the existing studies contain no analyses of the implications of public investment efficiency for the welfare effects of public investment. The depreciation rate of public capital also affects the stock of public capital. The shorter the life spans of public capital, the smaller the welfare multiplier. In addition, the larger the output elasticity of public capital, the higher the welfare multiplier, because the supply-side effect of fiscal policy depends on the output elasticity of public capital. This result is consistent with earlier studies (Rioja 1999, Bom and Ligthart 2014, and Sims and Wolff 2018).

The second main finding is that the welfare multiplier of public investment is positive - and sizable - in cases where the parameter values of the key variables derive from the empirical estimates for advanced economies. The IMF (2015) estimates the annual public capital depreciation rate is $5 \%$ and the average efficiency gap in public investment is $13 \%$ in advanced economies. We set the efficiency of public investment at 0.87 , which implies that one dollar of public investment translates into 0.87 dollars of public capital. Bom and Ligthart's (2013) 
meta-analysis concludes that the output elasticity of public capital is 0.083 . With these numbers, the cumulative output multiplier of fiscal policy over five years is 1.5 . This is perfectly in line with the empirical estimate of the IMF (2014), which lends credibility to the welfare analysis. The welfare multiplier is 1.4: A one dollar increase in public investment yields a welfare gain corresponding to a 1.4 dollar increase in private consumption or, alternatively interpreted, that households are willing to pay 1.4 dollars for a one dollar rise in public investment spending. The gains in productivity linked to enhanced public capital imply an increase in private consumption without an identical increase in labor supply. The policy implication for advanced economies is that a public investment push is desirable from a welfare point of view. Our finding is in line with Sims and Wolff (2018). However, our welfare multiplier is much higher than theirs, as discussed below.

The third main finding - and the most prominent - is that the welfare multiplier of public investment is likely to be roughly zero in developing economies. Taking into account the inefficiency of public investment is more important in developing economies, where low efficiency is more serious problem. We set the efficiency of public investment for developing economies at 0.57, which is the average of the estimates of Dabla-Norris (2012), Gupta et al. (2014), and the IMF (2015). The output elasticity of public capital may be lower in developing economies (Bom and Ligthart 2013) and we set it at 4\%. With these numbers, together with the annual public capital depreciation rate $5 \%$, the welfare multiplier of public investment is 0.039. This finding is new as the existing literature contains no analysis of the welfare multiplier of public investment in developing economies. The cumulative output multiplier over five years is 0.76 , consistent with the IMF's (2014) empirical evidence for developing economies. We also find that a low public investment efficiency lowers the output multiplier of fiscal policy. This is consistent with the IMF's (2014) finding that public investment has a smaller growth effect in low-efficiency countries. Our calculation shows that if all low and middle income countries improve the efficiency of public investment from 0.57 to 0.73 (the IMF's 2015 estimate for emerging economies), holding the level of public investment constant, this will boost the annual GDP of low and middle income countries by 522 billion U.S. dollars in ten years. Potential gains from an improvement in public investment efficiency are thus considerable for developing economies.

The policy implications of low public investment efficiency are debated. Pritchett (2000) claims that low public investment efficiency in developing countries is problematic, because public investment has a weak effect on economic performance. The IMF (2014) argues that for this reason low-efficiency countries should raise public investment efficiency. On the other hand, Berg et al. (2019) claim since the efficiency and scarcity of public capital are inversely related across countries in theoretical growth models, the productivity (output elasticity) of public capital is higher in low-efficiency countries. Therefore, the output effect of public investment is at least identical in low-efficiency countries. Our paper offers a different 
perspective on this debate. First, the IMF (2014) finds that the output multiplier of public investment in advanced economies is double that of developing economies. Second, the IMF (2015) shows that the efficiency of public investment is much higher in advanced economies than developing economies. In a DSGE model, these two findings cannot be reconciled without assuming less public capital productivity in developing countries. Both the efficiency and productivity of public investment are thus likely to be lower in developing countries and they may both be so low that the welfare multiplier of public investment is roughly zero. Developing economies should raise the efficiency and productivity of public investment.

The fourth main finding of our paper is that a fraction of the welfare gains of public investment leaks abroad. Sims and Wolff (2018), who use a closed-economy model of the U.S with full public investment efficiency, is the only paper analyzing the welfare multiplier of public investment. Their welfare multiplier is 0.3 . In Sims and Wolff (2018), the (domestic) welfare multiplier takes all welfare effects into account. In open economies, a fiscal expansion raises the demand for foreign goods, increasing foreign income, and the improvement of the foreign terms of trade increases foreign consumption. The positive welfare spillover effect implies that the (domestic) welfare multiplier is smaller than the world welfare multiplier. In our model, the world welfare multiplier, using the parameterization of Sims and Wolff (2018), is 0.3. This is fully consistent with Sims and Wolff (2018). However, our (domestic) welfare multiplier is only 0.2 , so that roughly one third of the overall welfare gain leaks abroad. However, Sims and Wolff (2018) may underestimate the welfare gains of public investment, even if they assume full public investment efficiency and use a closed-economy model. First, they set the productivity of public capital at 5\%; according to the meta-analysis by Bom and Ligthart (2013) it is $8 \%$. Second, they set the annual depreciation rate at $10 \%$; according to the IMF (2015) it is 5\%. Therefore, our welfare multiplier of choice (1.4) is roughly four times that of Sims and Wolff (2018).

The rest of the paper is organized as follows: Section 2 introduces the model. Section 3 discusses the parameterization. Section 4 analyzes the output and welfare multipliers of fiscal policy. Section 5 concludes the paper.

\section{MODEL}

There are two countries in the world, which we label home and foreign. The world population is normalized to one and there is a continuum of firms and households indexed by $z \in[0,1]$. A fraction $n(1-n)$ of households and firms are domestic (foreign). We look at two kinds of public spending: consumption and investment. 


\subsection{Demand Side: Households}

All households have identical preferences. The utility function of the representative domestic household is given by

$$
U_{t}=\sum_{s=t}^{\infty} \beta^{s-t}\left[\log C_{s}-\frac{\left(l_{s}(z)\right)^{1+\frac{1}{v}}}{1+\frac{1}{v}}+\vartheta \log G_{s}^{C}\right]
$$

where $0<\beta<1$ is the discount factor, $\mathrm{C}_{t}$ is a private consumption index, $l_{t}(z)$ is the household's labor supply, $v$ is the Frisch elasticity of labor supply, $G_{t}^{C}$ is a public consumption index, and $\vartheta$ is the weight of public consumption relative to private consumption.

The private consumption index is defined as

$$
C_{t}=\left[n \alpha^{\frac{1}{\rho}}\left(C_{t}^{h}\right)^{\frac{\rho-1}{1}}+(1-n \alpha)^{\frac{1}{\rho}}\left(C_{t}^{f}\right)^{\frac{\rho-1}{\rho}}\right]^{\frac{\rho}{\rho-1}}
$$

where $C_{t}^{h}\left(C_{t}^{f}\right)$ is an index of domestic (foreign) goods and $\rho>0$ is the elasticity of substitution between domestic and foreign goods (cross-country substitutability). In this setup, $n \alpha(0<$ $n \alpha<1)$ is the proportion of domestic goods in the consumption basket, and the parameter $\alpha$ $>1$ captures the degree of home bias in consumption. The public consumption indexes are identical to the private consumption ones. In addition, an analogous index governs public infrastructure spending. The consumption of domestic and foreign goods $C_{t}^{h}$ and $C_{t}^{f}$ are aggregates defined as follows

$$
C_{t}^{h}=\left[n^{-\frac{1}{\theta}} \int_{0}^{n}\left(c_{t}^{h}(z)\right)^{\frac{\theta-1}{\theta}} d z\right]^{\frac{\theta}{\theta-1}}, C_{t}^{f}=\left[(1-n)^{-\frac{1}{\theta}} \int_{n}^{1}\left(c_{t}^{f}(z)\right)^{\frac{\theta-1}{\theta}} d z\right]^{\frac{\theta}{\theta-1}}
$$

where $c_{t}^{h}(z)\left(c_{t}^{f}(\mathrm{z})\right)$ is the consumption of differentiated domestic (foreign) good $z$ by the representative domestic household, and $\theta>1$ is the elasticity of substitution between two goods produced in the same country (within-country substitutability).

The foreign private consumption index is

$$
C_{t}^{*}=\left[n \alpha^{* \frac{1}{\rho}}\left(C_{t}^{* h}\right)^{\frac{\rho-1}{\rho}}+\left(1-n \alpha^{*}\right)^{\frac{1}{\rho}}\left(C_{t}^{* f}\right)^{\frac{\rho-1}{\rho}}\right]^{\frac{\rho}{\rho-1}}
$$

where asterisks indicate consumption by the representative foreign household, and $\mathrm{n} \alpha^{*}$ $\left(0<n \alpha^{*}<1\right)$ is the proportion of domestic goods in the foreign consumption basket. We assume home bias in consumption, requiring $\alpha^{*}<1$. 
Given the consumption indexes, the private demand functions for the differentiated domestic and foreign goods by domestic and foreign households are, with obvious notation

$$
\begin{aligned}
& c_{t}^{h}(z)=\left[\frac{p_{t}^{h}(z)}{P_{t}^{h}}\right]^{-\theta}\left[\frac{P_{t}^{h}}{P_{t}}\right]^{-\rho} \alpha C_{t}, c_{t}^{f}(z)=\left[\frac{p_{t}^{f}(z)}{P_{t}^{f}}\right]^{-\theta}\left[\frac{P_{t}^{f}}{P_{t}}\right]^{-\rho}\left(\frac{1-n \alpha}{1-n}\right) C_{t}, \\
& c_{t}^{* h}(z)=\left[\frac{p_{t}^{* h}(z)}{P_{t}^{* h}}\right]^{-\theta}\left[\frac{P_{t}^{* h}}{P_{t}}\right]^{-\rho} \alpha^{*} C_{t}^{*}, c_{t}^{* f}(z)=\left[\frac{p_{t}^{* f}(z)}{P_{t}^{* f}}\right]^{-\theta}\left[\frac{P_{t}^{* f}}{P_{t}^{*}}\right]^{-\rho}\left(\frac{1-n \alpha^{*}}{1-n}\right) C_{t}^{*} .
\end{aligned}
$$

The public demand functions for the domestic and foreign goods by domestic and foreign governments are defined in an analogous way. In these demand functions, $p_{t}^{h}(z)$ and $p_{t}^{f}(z)$ denote the domestic currency price of domestic and foreign goods, respectively, while $P_{t}^{h}$ and $P_{t}^{f}$ are the price indexes that correspond to domestic and foreign aggregate consumption baskets $C_{t}^{h}$ and $C_{t}^{f}$. Price indexes are expressed in terms of the local currency, and corresponding foreign currency price indexes are denoted by an asterisk; e.g., $p_{t}^{* h}(z)$ is the foreign currency price of a differentiated domestic brand. $P_{t}^{h}$ and $P_{t}^{f}$ are defined as

$$
\begin{aligned}
& P_{t}^{h}=\left[n^{-1} \int_{0}^{n}\left(p_{t}^{h}(z)\right)^{1-\theta} d z\right]^{\frac{1}{1-\theta}}, \\
& P_{t}^{f}=\left[(1-n)^{-1} \int_{n}^{1}\left(p_{t}^{f}(z)\right)^{1-\theta} d z\right]^{\frac{1}{1-\theta}} .
\end{aligned}
$$

The overall domestic price index is

$$
P_{t}=\left[n \alpha\left(P_{t}^{h}\right)^{1-p}+(1-n \alpha)\left(P_{t}^{f}(\tau)\right)^{1-p}\right]^{\frac{1}{1-p}}
$$

The corresponding foreign indexes are defined in an analogous way.

The budget constraint of the domestic household is given by

$$
D_{t}=\left(1+i_{t-1}\right) D_{t-1}+w_{t} l_{t}(z)-P_{t} C_{t}+\pi_{t}-P_{t} T_{t},
$$

where $D_{t}$ is domestic nominal bonds held at the end of period t (bonds pay one domestic currency period $t+1), i_{t}$ is the nominal interest rate on bonds between $\mathrm{t}-1$ and $\mathrm{t}, w_{t}$ is the nominal wage, $\pi_{t}$ is nominal dividends (profits) of domestic firms, and $T_{t}$ is lump-sum taxes. The only internationally traded asset is the domestic bond. The global asset-market clearing condition implies that $n D_{t}+(1-n) D_{t}^{*}=0$. 
The foreign economy is similar to the domestic one, except for the fact that the foreign bond $\left(\mathrm{F}^{*}\right)$, denominated in the foreign currency, is not traded internationally. The net supply of foreign bonds is zero, because the foreign country has only the representative household. The budget constraint of the foreign household is

$$
\frac{D_{t}^{*}}{s_{t}}+F_{t}^{*}=\left(1+i_{t}\right) \frac{D_{t-1}^{*}}{s_{t}}+\left(1+i_{t}^{*}\right) F_{t-1}^{*}+w_{t}^{*} l_{t}^{*}(z)-P_{t}^{*} C_{t}^{*}+\pi_{t}^{*}+P_{t}^{*} T_{t}^{*}
$$

where $S_{t}$ is the nominal exchange rate, defined as the price of the foreign currency expressed in the domestic currency. Consequently, an increase in this is an exchange rate depreciation of the domestic currency.

In order to ensure the stationarity of the model, we follow Schmitt-Grohe and Uribe (2003) and assume that net foreign debt increases the domestic interest rate. This is done by including a risk premium that forces external debt in the long term to return to the initial (zero) level. The interest parity condition with risk premium is given by

$$
\left(1+i_{t}\right)=\left(1+i_{t}^{*}\right) \frac{s_{t+1}}{s_{t}}+\psi\left(\exp \left(D_{t}\right)-1\right)
$$

where $\psi\left(\exp \left(D_{t}\right)-1\right)$ is the risk premium.

The representative domestic household's optimality conditions are

$$
\begin{aligned}
& 1=\beta\left(1+i_{t}\right) \frac{P_{t} C_{t}}{P_{t} C_{t+1}}, \\
& l_{t}(z)=\left(\frac{w_{t}}{C_{t} P_{t}}\right)^{v} .
\end{aligned}
$$

Equation (3) implies that households smooth consumption intertemporally. Equation (4) governs the optimal labor supply. The labor supply is an increasing function of the real wage and a decreasing function of private consumption.

\subsection{Monetary and Fiscal Policy}

The government budget constraint in per-capita terms can be expressed as

$$
T_{t}=G_{t}^{I}+G_{t}^{C}
$$


where $G^{I}$ denotes public investment spending. We use non-distortionary taxes since we wish to isolate the effects of interest on the spending side of fiscal policy.

Both types of public spending follow an AR (1) process

$$
\widehat{G}_{t}^{i}=\rho^{i} \hat{G}_{t-1}^{i}+\varepsilon_{t}^{i},
$$

where $\mathrm{i}=\mathrm{I}, \mathrm{C}, \rho^{i} \in[0,1]$ and $\varepsilon_{t}^{i}$ is a zero mean white-noise process representing an unexpected change in public spending. Percentage changes from the initial steady state (denoted by the subscript zero) are denoted by hats (for example: $\hat{x}_{t}=d x_{t} / x_{0}$ ). Variables whose initial value is zero, such as initial bond holdings, are normalized by the initial level of GDP.

The central bank adjust the nominal interest rate according to a log-linear Taylor rule with interest rate smoothing

$$
\hat{\imath}_{t}=\left(1-\mu_{1}\right) \mu_{2} \Delta \hat{P}_{t}+\mu_{1} \hat{\imath}_{t-1},
$$

where coefficients $\mu_{1}$ and $\mu_{2}$ are non-negative and $\Delta$ is the first difference operator. If the economy was at the zero lower bound, welfare multipliers could be somewhat different. However, Rendhal (2016) has already analyzed the welfare multiplier of fiscal policy in a liquidity trap. In addition, the effects of a public investment shock in the current version of the model are substantially in line with the empirical evidence.

\subsection{Supply Side: Firms}

Iwata (2013) emphasizes that it is customary in the literature (including Basu and Kollmann 2013, Bom and Ligthart 2014, Iwata 2013, Rioja 1999, and Sims and Wolff 2018) to assume that firms face constant returns to scale in the private factors of production and increasing returns to scale in all factors due to the positive externality of public capital. As in Basu and Kollmann (2013), we assume the simplest version of the production function with public capital. All firms produce differentiated goods with the production function

$$
y_{t}(z)=l_{t}(z)\left(K_{t}^{G}\right)^{\varnothing}
$$

where $y_{t}(z)$ is the output of the representative firm $Z, l_{t}(z)$ is the labor input, $K_{t}^{G}$ is the public capital stock, and $\varnothing$ is the output elasticity of public capital. The omission of private capital makes the model simpler and more transparent and allows us derive a simple equation that describes private productivity in terms of the key parameters of the model. The empirical result of the IMF (2014) is that public investment does not crowd private investment out or in, so that 
this omission may not have significant implications for the welfare multiplier of public investment.

Prichett (2000) criticizes the standard versions of the accumulation of public capital where every dollar of public investment spending creates valuable public capital always and everywhere. Several empirical studies support the view that there are notable inefficiencies in public investment (Caselli 2005, Dabla-Norris et al. 2012, Gupta et al. 2014, IMF 2015). Following Prichett (2000), we assume that only a fraction of the actual accounting cost of public investment translates into the value of public capital. The accumulation of public capital is given by

$$
K_{t+1}^{G}=(1-\delta) K_{t}^{G}+\zeta G_{t}^{I}
$$

where $\delta$ is the depreciation rate of public capital and $\zeta(0<\zeta \leq 1)$ is public investment efficiency. $\zeta$ is in a way isomorphic to the marginal efficiency of investment of Justiniano et al. (2011), which they define as the process where (private) investment is transformed into (private) capital to be used in production. The existing theoretical business-cycle literature with public capital assumes that $\zeta=1$, which implies the perfect efficiency of public investment. The steady state (SS) public capital is $K_{S S}^{G}=\zeta G_{S S}^{I} / \delta$.

Equation (6) means that private productivity, denoted by $A_{t}$, can be defined as $A_{t}=\left(K_{t}^{G}\right)^{\emptyset}$. We can write it in terms of investment by iterating the public capital accumulation equation backwards: $A_{t}=\left[\sum_{s=1}^{\infty}(1-\delta)^{s} \zeta G_{t-s}^{I}\right]^{\varnothing}$. We can illustrate the intuition behind the main results by taking log of it to get

$$
\ln A_{t}=\varnothing\left[\ln \sum_{s=1}^{\infty}(1-\delta)^{s} \zeta G_{t-s}^{I}\right]
$$

Equation (7) illustrates that private productivity, for a given level of public investment, is higher, (i) the bigger is the output elasticity of public capital $(\varnothing)$, (ii) the bigger is the efficiency of public investment $(\zeta)$, and (iii) the smaller is the depreciation rate $(\delta)$. On the other hand, it shows that it is hard to specify the distinction between $\emptyset$ and $\zeta$ as a contribution.

The domestic firm maximizes its profits

$$
\pi_{t}(z)=p_{t}^{h}(z) y_{t}(z)-w_{t} l_{t}(z)
$$

taking into account the production function (6) and the demand for its goods 
$y_{t}(z)=\left[\frac{p_{t}^{h}(z)}{P_{t}^{h}}\right]^{-\theta}\left[\frac{P_{t}^{h}}{P_{t}}\right]^{-\rho} n \alpha\left(C_{t}+G_{t}^{A}\right)+\left[\frac{p_{t}^{h}(z)}{S_{t} P_{t}^{* h}}\right]^{-\theta}\left[\frac{S_{t} P_{t}^{* h}}{S_{t} P_{t}^{*}}\right]^{-\rho}(1-n) \alpha^{*}\left(C_{t}^{*}+G_{t}^{* A}\right)$,

where $G_{t}^{A}$ is aggregate public spending $\left(G_{t}^{A}=G_{t}^{I}+G_{t}^{C}\right)$. Using equations (6) and (8), domestic profits can be expressed as

$$
\begin{gathered}
\pi_{t}(z)=\left[p_{t}^{h}(z)-\frac{w_{t}}{\left(K_{t}^{G}\right)^{\varnothing}}\right] \times \\
\left\{\left[\frac{p_{t}^{h}(z)}{P_{t}^{h}}\right]^{-\theta}\left[\frac{P_{t}^{h}}{P_{t}}\right]^{-\rho} n \alpha\left(C_{t}+G_{t}^{A}\right)+\left[\frac{p_{t}^{h}(z)}{S_{t} P_{t}^{* h}}\right]^{-\theta}\left[\frac{S_{t} P_{t}^{* h}}{S_{t} P_{t}^{*}}\right]^{-\rho}(1-n) \alpha^{*}\left(C_{t}^{*}+G_{t}^{* A}\right)\right\} .
\end{gathered}
$$

Under the flexible price solution of our model, the domestic firm would maximize equation (10) with respect to $p_{t}^{h}(z)$, implying

$$
p_{t}^{h}(z)=\frac{\theta}{\theta-1} \frac{w_{t}}{\left(K_{t}^{G}\right)^{\phi}}
$$

This expresses the notion that under flexible prices the price of the representative good is a constant mark-up, determined by within-country substitutability, over the marginal cost. However, we introduce nominal rigidities following Calvo (1983). Each firm can reset its prices with a probability of $1-\gamma$ in any given period, independently of the time elapsed since the last adjustment and of other firms. Under this framework, the domestic firm seeks to maximize

$$
\max _{p_{t}^{h}(z)} V_{t}(z)=\sum_{s=t}^{\infty} \gamma^{s-t} \zeta_{t, s} \pi_{s}(z)
$$

where $\zeta_{t, s}$ is the stochastic discount factor between periods $t$ and $s$. The result is

$$
p_{t}^{h}(z)=\left(\frac{\theta}{\theta-1}\right) \frac{\sum_{s=t}^{\infty} \gamma^{s-t} \zeta_{t, s} Q_{s} \frac{w_{S}}{\left(K_{S}^{G}\right)^{\phi}}}{\sum_{s=t}^{\infty} \gamma^{s-t} \zeta_{t, s} Q_{s}}
$$

where $Q_{t}=\left[\frac{1}{P_{t}^{h}}\right]^{-\theta}\left[\frac{P_{t}^{h}}{P_{t}}\right]^{-\rho} n \alpha\left(C_{t}+G_{t}^{A}\right)+\left[\frac{1}{s_{t} P_{t}^{* h}}\right]^{-\theta}\left[\frac{s_{t} P_{t}^{* h}}{s_{t} P_{t}^{*}}\right]^{-\rho}(1-n) \alpha^{*}\left(C_{t}^{*}+G_{t}^{* A}\right)$.

A convenient way of looking at the solution is to log-linearize it as follows

$\hat{p}_{t}^{h}(z)=\beta \gamma \hat{p}_{t+1}^{h}(z)+(1-\beta \gamma)\left(\widehat{w}_{t}-\emptyset \widehat{K}_{t}^{G}\right)$. 
This shows that the change in the optimal price is a weighted average of the changes in current and future marginal costs, and that an increase in the public capital stock reduces the optimal price.

\subsection{Consolidated Budget Constraint}

The consolidated budget constraint of the domestic economy can be derived by plugging equations (5) and (8) into equation (2), as follows ${ }^{2}$

$$
D_{t}-\left(1+i_{t}\right) D_{t-1}=p_{t}^{h}(z) y_{t}(z)-P_{t} C_{t}-P_{t} G_{t}^{I}-P_{t} G_{t}^{C}
$$

We define the current account as the change in net foreign assets (following Obstfeld and Rogoff 1995)

$$
\mathrm{C} A_{t}=D_{t}-D_{t-1}=i_{t} D_{t-1}+p_{t}^{h}(z) y_{t}(z)-P_{t} C_{t}-P_{t} G_{t}^{I}-P_{t} G_{t}^{C}
$$

The current account is the sum of the service account (interest income) and the trade balance account, defined as the difference between the value of domestic output and the sum of private and public consumption and public investment.

\subsection{Initial Steady State}

We log-linearize the model around a symmetric steady state where initial net foreign assets are zero $\left(D_{0}=0\right)$. The consolidated budget constraint of the domestic economy (12) implies $y_{0}=$ $C_{0}+G_{0}^{C}+G_{0}^{I}$. This and equations (4), (6) and (11) imply that the initial level of employment is

$$
l_{0}(z)=\left[\left(\frac{\theta-1}{\theta}\right)\left(\frac{y_{0}}{C_{0}}\right)\right]^{\frac{1}{1+1 / v}}
$$

\section{Parameterization}

We analyze the output and welfare multipliers of fiscal policy in advanced and developing economies, which may differ in many aspects. We assume, however, that they differ only in

\footnotetext{
${ }^{2}$ The consolidated budget constraint for the foreign economy, which takes into account the market-clearing condition for domestic bonds and that the net supply of the foreign bond is zero, is

$\frac{n}{1-n} \frac{D_{t}}{S_{t}}-\left(1+i_{t}\right) \frac{n}{1-n} \frac{D_{t-1}}{S_{t}}=p_{t}^{* f}(z) y_{t}^{*}(z)-P_{t}^{*} C_{t}^{* I}-P_{t}^{*} G_{t}^{* I}-P_{t}^{*} G_{t}^{* C}$.
} 
two aspects. Developing economies have a lower public investment efficiency, consistent with the empirical evidence of the IMF (2015) and a lower productivity of public capital, to be able to match the empirically observed output multiplier of public investment in developing economies. The parameterization of the model is typically chosen to match the features of advanced economies, notably the U.S., the euro area and Japan.

The two countries are of equal size $(\mathrm{n}=0.5)$. We set the discount factor $\beta$ at 0.995 , as in Sims and Wolff (2018). Since we interpret our periods as quarters, this is equivalent to a $2 \%$ annual real interest rate. The within-country substitutability parameter $(\theta)$ is set it at 11 , as in Sims and Wolff (2018). This implies a 10 percent price markup over the marginal cost in the steady state. Cross-country substitutability $(\rho)$ is set at 1.5 , a commonly used value in international macroeconomics and consistent with the estimate by Dong (2012). Based on existing evidence and surveys (Keane and Rogerson 2012 and Chetty et al. 2013), the Frisch elasticity of labor supply $(v)$ is set at 0.7 . The Calvo parameter $(\gamma)$ is set at 0.5 . This value is widely used in New Keynesian models and implies an average delay of two periods (six months) between price adjustments, consistent with the evidence of Bils and Klenow (2004).

We set the home bias parameter such that the import to GDP ratio is realistic. We set $\alpha$ at 1.68 and $\alpha^{*}=(1-n \alpha) / n=0.32$, so that the import to GDP ratio $(1-n \alpha$ in the home country) is $16 \%$ in both countries, which corresponds to the observed ratio in recent years in the U.S., and Japan, and the Euro area (World Bank 2018 and Coenen 2013).

The risk premium in the UIP $(\psi)$ is set at 0.004, based on the findings of Bergin (2006). A net external debt of 10 percent of GDP increases the domestic interest rate by four basis points relative to the foreign country. The Taylor rule coefficients are set as $\mu_{1}=0.79$ and $\mu_{2}=1.5$, following Clarida et al. (2000) and Taylor (1993).

According to the IMF (2014), the average public investment to GDP ratio in a group of 34 advanced economies in 2000-2011 was 3.3\% and in a group of 154 emerging and developing economies $8.2 \%$. As discussed, since the parameterization of the model is typically chosen to match the features of advanced economies, the ratio of public investment to GDP is set at 0.03. According to the World Bank (2018), the average ratio of public consumption to GDP in high income countries in 2000-2011 was $18 \%$ and in low and middle countries $14 \%$. The ratio of public consumption to GDP is set at $18 \%$. Consequently, the ratio of private consumption to GDP is 0.79 . In fact, the above-mentioned numbers imply that the ratio is also realistic for developing economies. 
Table 1. Parameterization of the Model

\begin{tabular}{|c|c|c|c|}
\hline Parameter & Baseline value & Description & Source \\
\hline$\beta$ & 0.995 & Discount factor & Sims and Wolff (2018) \\
\hline$n$ & 0.5 & $\begin{array}{l}\text { Relative size of the } \\
\text { domestic economy }\end{array}$ & \\
\hline$\theta$ & 11 & $\begin{array}{l}\text { Within-country } \\
\text { substitutability }\end{array}$ & $\begin{array}{l}\text { Basu and Fernald (1997) } \\
\text { \& Sims and Wolff (2018) }\end{array}$ \\
\hline$\rho$ & 1.5 & $\begin{array}{l}\text { Cross-country } \\
\text { substitutability }\end{array}$ & Dong (2012) \\
\hline$v$ & 0.7 & $\begin{array}{l}\text { Frisch elasticity of labor } \\
\text { supply }\end{array}$ & $\begin{array}{l}\text { Keane and Rogerson } \\
\text { (2012) \& Chetty et al } \\
\text { (2013) }\end{array}$ \\
\hline$\gamma$ & 0.5 & Calvo parameter & Bils and Klenow (2004) \\
\hline$\alpha$ & 1.68 & Home bias parameter & $\begin{array}{c}\text { Coenen (2013) \& World } \\
\text { Bank (2018) }\end{array}$ \\
\hline$\alpha^{*}$ & 0.32 & Home bias parameter & $\begin{array}{c}\text { Coenen (2013) \& World } \\
\text { Bank (2018) }\end{array}$ \\
\hline$\psi$ & 0.004 & Risk premium in UIP & Bergin $(2006)$ \\
\hline$\mu_{1}$ & 0.79 & Interest rate smoothing & Clarida et al. (2000) \\
\hline$\mu_{2}$ & 1.5 & $\begin{array}{l}\text { Coefficient for inflation in } \\
\text { the monetary policy rule }\end{array}$ & Taylor (1993) \\
\hline$G_{0}^{I} / y_{0}$ & 0.03 & $\begin{array}{c}\text { Public investment to GDP } \\
\text { ratio }\end{array}$ & IMF (2014) \\
\hline$G_{0}^{C} / y_{0}$ & 0.18 & $\begin{array}{l}\text { Public consumption to } \\
\text { GDP ratio }\end{array}$ & World Bank (2018) \\
\hline$\rho^{I}, \rho^{C}$ & 0.75 & $\begin{array}{l}\text { Persistency of public } \\
\text { spending shocks }\end{array}$ & Iwata (2013) \\
\hline$\vartheta$ & 0.4 & $\begin{array}{l}\text { Weight of public } \\
\text { consumption }\end{array}$ & Song et al. (2012) \\
\hline$\delta$ & 0.0125 & $\begin{array}{c}\text { Depreciation rate of public } \\
\text { capital }\end{array}$ & IMF (2014) \\
\hline$\phi$ & 0.083 & $\begin{array}{c}\text { Output elasticity of public } \\
\text { capital }\end{array}$ & Bom and Ligthart (2013) \\
\hline$\zeta$ & 0.87 & $\begin{array}{c}\text { Efficiency of public } \\
\text { investment in advanced } \\
\text { economies }\end{array}$ & IMF (2015) \\
\hline$\zeta$ & 0.57 & $\begin{array}{c}\text { Efficiency of public } \\
\text { investment in developing } \\
\text { economies }\end{array}$ & $\begin{array}{c}\text { Dabla-Norris (2012), } \\
\text { Gupta et al. (2014) \& IMF } \\
\text { (2015) }\end{array}$ \\
\hline
\end{tabular}


The persistency of public investment and consumption shocks is set at $0.75\left(\rho^{i}=0.75, \mathrm{i}=\mathrm{I}\right.$, C), based on the findings of Iwata (2013). The sizes of shocks $\left(\varepsilon^{I}, \varepsilon^{C}\right)$ are set at 1 percent of initial GDP. The weight of public consumption to relative private consumption $(\vartheta)$ is a very poorly identified parameter. The larger is $\vartheta$, the higher the utility weight households place on public consumption. We set it at 0.4, following Song et al. (2012)). The welfare multiplier of public consumption is very sensitive to it and we explain how the multiplier depends on it in section 4.1 .

Equation (7) shows that the results are sensitive to the output elasticity of public capital $(\phi)$, the public capital depreciation rate $(\delta)$, and the efficiency of public investment $(\zeta)$. Given the quite wide range of estimates for the output elasticity of public capital, we rely on the metaanalysis carried out by Bom and Ligthart (2013), who use a sample of 578 estimates collected from 68 studies, concluding that the short-term output elasticity of public capital supplied at the central government level is 0.083 . Accordingly, we set the benchmark value at 0.083 . In the sensitivity analysis, we vary it within the range of 0.02 to 0.1 .

Rioja (1999), Bom and Ligthart (2014) and Sims and Wolff (2018) set a 10\% annual depreciation rate of public capital. Bom and Ligthart (2014) and Sims and Wolff (2018) use this value without any explanation. Rioja $(1999,396)$ argues that "depreciation rates of public and private capital are set to be equal given that there are no known studies to the author that estimate them separately". The annual $10 \%$ depreciation rate is typically chosen to match the depreciation rate of private capital. Today, the foundations for setting the annual $10 \%$ depreciation rate for public capital, however, seems weak. Kamps (2006) calculates that the annual depreciation rate of public capital has increased from $2.5 \%$ to $4 \%$ in the U.S. He argues that this rise may reflect an increasing weight of assets with relatively short life spans and a shortening of assets' life spans. He argues that these developments are characteristic of ICTrelated assets. Gupta et al. (2014) build a public capital stock series that takes into account the efficiency of public investment using the annual depreciation rate of $2.5 \%$ for low-income countries and $4.3 \%$ for middle-income countries.

The IMF $(2015,47)$ argues that depreciation rates are "likely to increase with income assuming that the share of assets with a shorter life spans (such as technology assets) rises with income levels." It follows the logic of Kamps (2006) and Gupta et al. (2014) and sets the time-varying depreciation rates of capital in the estimation of public investment efficiency and the public capital stock. It sets the depreciation rate of public capital at $2.5 \%$ for low-income countries, $3.5 \%$ for middle-income countries and $4.6 \%$ for high-income countries in 2013, while the private capital depreciation rate in high-income countries was $10 \%$. In fact, the numbers for high-income countries are based on empirical evidence from the U.S., Australia and Canada. These numbers indicate that we should set the annual depreciation rate of public capital well 
below $10 \%$. In the baseline parameterization, we set the quarterly depreciation rate at $1.25 \%$ $(\delta=0.0125)$, which implies a $5 \%$ annual depreciation rate.

The main innovation of the paper-relative to macro models exploring the welfare effects of public investment - is the incomplete efficiency of public investment. Therefore, the choice of $\zeta$ is worthy of a comment. Dabla-Norris et al. (2012) construct a public investment efficiency index that can be used in macro models as a proxy for $\zeta$. They find that the average index is 0.42 in a group of 71 low and middle income countries. They do, however, find a large range of estimates (0.07-0.88) and argue that "implications should also be examined for the wide range of [ל] values" (Dabla-Norris et al. 2012, 258). Gupta et al. (2014) construct a public capital stock series that takes into account the efficiency of public investment using the same 71 countries. They find that only about half of public investment spending translates into public capital as their average estimate of $\zeta$ is 0.51 .

The IMF (2015) develops a public investment efficiency indicator that evaluates the relationship between the stock of public capital and indicators of the quality and coverage of public infrastructure assets. Countries with the highest levels of public infrastructure coverage and quality for given levels of the public capital stock and per-capita income form the basis of an efficiency frontier and get an index score of 1 . Countries are given an index score of 0 and 1 , based on their distance to the frontier relative to the peer group's best performers. The greater the distance from the frontier, the less efficient the country's public investment, and lower its index score. A physical indication, which uses data on the volume of economic and social infrastructure, measures of the coverage of physical output of public investment. A surveybased indicator based on the World Economic Forum's survey on the impression of the quality of public infrastructure services measures of the quality of public infrastructure assets. The hybrid indicator, which joins the indicators, is 0.87 in advanced economies, 0.73 in emerging economics, and 0.6 in low income developing countries.

We believe that the IMF's (2015) public investment efficiency index is the best estimate for $\zeta$ for advanced economies and set it at 0.87 . We set it at 0.57 for developing economies, which is the average of the estimates of Dabla-Norris (2012), Gupta et al. (2014), and the IMF (2015) for emerging economics and low and middle income countries. We analyze the sensitivity of the key results varying $\zeta$ from 0.57 to $1 .^{3}$

\section{Output and Welfare Multipliers of Public Spending}

In this section, we present the results on the output and welfare multipliers of fiscal stimulus. The cumulative multiplier $(\mathrm{CM})$ is defined as the cumulative change in output over the

\footnotetext{
${ }^{3}$ We simulate the model using the algorithm developed by McCallum (2001) and Klein (2000)
} 
cumulative change of public spending as a percentage of GDP (see, for example, Gechert and Rannenberg 2014)

$$
C M=\frac{\sum_{h} d Y_{t+h}}{\sum_{h} d G_{t+h}^{i}}
$$

The net present value fiscal multiplier (NPVM) is the sum of output over a certain time horizon (we use 2,000 periods) discounted at the steady state interest rate, and divided by public spending discounted in the same way (see Uhlig 2010):

$$
N P V M=\frac{\sum_{s=t}^{h} \beta^{s-t} d Y_{S}}{\sum_{s=t}^{h} \beta^{s-t} d G_{s}^{i}}
$$

We calculate not only the net present value output multiplier but also the net present value welfare multiplier. In calculating the welfare multiplier, we follow Engler and Tervala (2018), Rendhal (2016) and Sims and Wolff (2018), who define it as the one period consumption equivalent change in the present discounted value of flow utility for a one unit (dollar) change in public spending. First, we measure the welfare effect of fiscal policy as a percentage of initial consumption that the household is willing to pay for fiscal expansion to be as well off in the fiscal expansion case as in the initial equilibrium (see Schmitt-Grohe and Uribe 2007).

Let $\left\{C_{S}^{W F E}, G_{S}^{W F E-C}, l_{s}^{W F E}(z)\right\}_{s=t}^{\infty}$ be the private and public consumption and labor supply paths without fiscal expansion (WFE). The associated net present value (NPV) of welfare is given by

$$
U_{N P V}^{W F E}=\sum_{S=t}^{\infty} \beta^{s-t}\left[\log \left(C_{S}^{W F E}\right)-\frac{\left(l_{S}^{W F E}(z)\right)^{1+1 / v}}{1+1 / v}+v \log G_{S}^{W F E, C}\right]
$$

We define $\lambda_{N P V}$ as the NPV of the welfare effect of a fiscal expansion (FE) relative to a case without fiscal expansion. It is measured as the fraction of initial private consumption that the domestic household is willing to pay for domestic fiscal expansion. If $U_{N P V}^{F E}$ denotes the net present value of welfare in the fiscal expansion case, then

$$
\begin{aligned}
& U_{N P V}^{F E}=\sum_{s=t}^{\infty} \beta^{s-t}\left[\log \left(\left(1+\lambda_{N P V}\right) C_{s}^{F E}\right)-\frac{\left(l_{S}^{F E}(z)\right)^{1+1 / v}}{1+1 / v}+\vartheta \log G_{s}^{F E, C}\right] \\
& U_{N P V}^{F E}=\frac{1}{1-\beta} \log \left(1-\lambda_{N P V}\right)+U_{N P V}^{W F E} .
\end{aligned}
$$

We can solve for $\lambda_{N P V}$, and express the welfare effect of a fiscal expansion as the percentage (rather than as a fraction) of consumption, as follows

$$
\lambda_{N P V}^{\%}=100 \times\left[\exp (1-\beta)\left(U_{N P V}^{F E}-U_{N P V}^{W F E}\right)-1\right] .
$$


Taking a first-order Taylor expansion of the utility function (1), we have

$d U_{N P V}=U_{N P V}^{F E}-U_{0}=\sum_{s=t}^{\infty} \beta^{s-t} d U_{s}^{F E}=\sum_{s=t}^{\infty} \beta^{s-t}\left(\hat{C}_{s}^{F E}-\left(l_{0}(z)\right)^{1+\frac{1}{v}} \hat{l}_{s}^{W E}(z)+v \vartheta_{s}^{F E, c}\right.$.

Welfare without fiscal expansion would be the same as in the initial steady state. We derive the NPV of the welfare effect of fiscal expansion as the percentage of initial consumption by substituting the above equation into (14)

$$
\begin{aligned}
& \lambda_{N P V}^{\%}=100 \times\left[\operatorname { e x p } ( 1 - \beta ) \left(\sum _ { s = t } ^ { \infty } \beta ^ { s - t } \left(\hat{C}_{S}^{F E}-\right.\right.\right. \\
& \left.\left(l_{0}(z)\right)^{1+\frac{1}{v}} \hat{l}_{s}^{F E}(z)+\vartheta \hat{G}_{s}^{F E, C}\right] .
\end{aligned}
$$

Finally, we divide (15) by public spending discounted the same way to calculate the (domestic) welfare multiplier $\left(M_{U}\right)$ of fiscal policy:

$$
M_{U}=\frac{100 \times\left[\operatorname { e x p } ( 1 - \beta ) \left(\sum _ { s = t } ^ { \infty } \beta ^ { s - t } \left(\hat{C}_{S}^{F E}-\left(l_{0}(z)\right)^{\left.\left.1+\frac{1}{v} \hat{\imath}_{s}^{F E}(z)+\vartheta \hat{G}_{s}^{F E, C}\right)-1\right]}\right.\right.\right.}{\sum_{s=t}^{\infty} \beta^{S-t} \hat{G}_{S}^{i}}
$$

This welfare multiplier is the consumption equivalent change in welfare for a one dollar change in public spending. If the welfare multiplier is 0.5 , one dollar increase in public spending yields a welfare improvement that corresponds 0.5 dollars increase in domestic private consumption.

Our open economy framework enables the analysis of the welfare multiplier for the world economy, while Sims and Wolff (2018) determine welfare multipliers in the closed economy. The world welfare multiplier is the sum of the consumption equivalent changes in welfare for a one dollar change in domestic public spending:

$$
M_{U}^{W}=\frac{\lambda_{N P V}^{\%}+\lambda_{N P V}^{* \%}}{\sum_{S=t}^{\infty} \beta^{s-t} \widehat{G}_{s}^{i}}
$$

In figure 1 we plot the value of fiscal expansion (not the welfare multiplier), measured by the percentage of initial consumption, that the household in willing to play for the fiscal expansion in period $t$ :

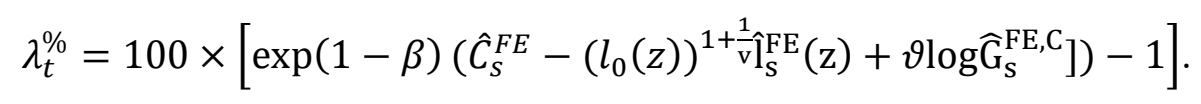




\subsection{Public Consumption}

Figure 1 shows the impulse responses of selected variables to a one percent of GDP increase in domestic public spending. The solid lines show the effects of a public consumption shock while the dashed lines show the effects of an investment shock in advanced economies. The terms of trade are defined as the ratio of the price of domestic exports to the price of imports. Generally speaking, variables are expressed in percentage deviations from the initial steady state. However, the change in the trade balance, whose initial value is zero, is expressed as deviations from initial GDP, inflation is expressed in percentage points in annual terms, and welfare is expressed in the percentage of initial consumption.

Figure 1. Effects of Fiscal Expansion. Source: All tables/figures, excluding Table 1, are based on authors' calculations.
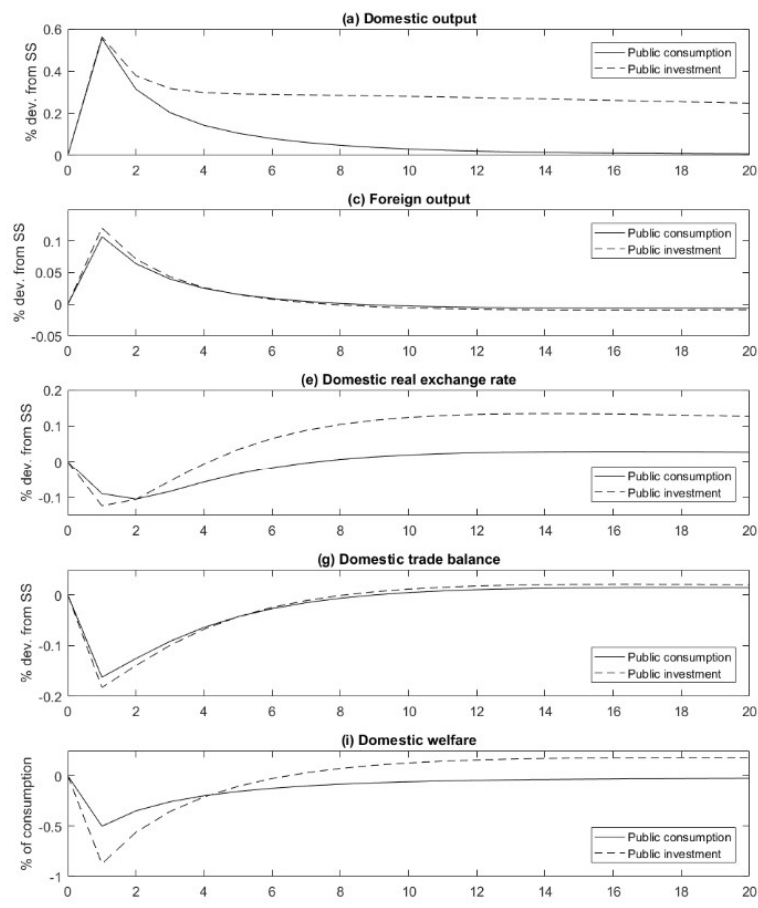
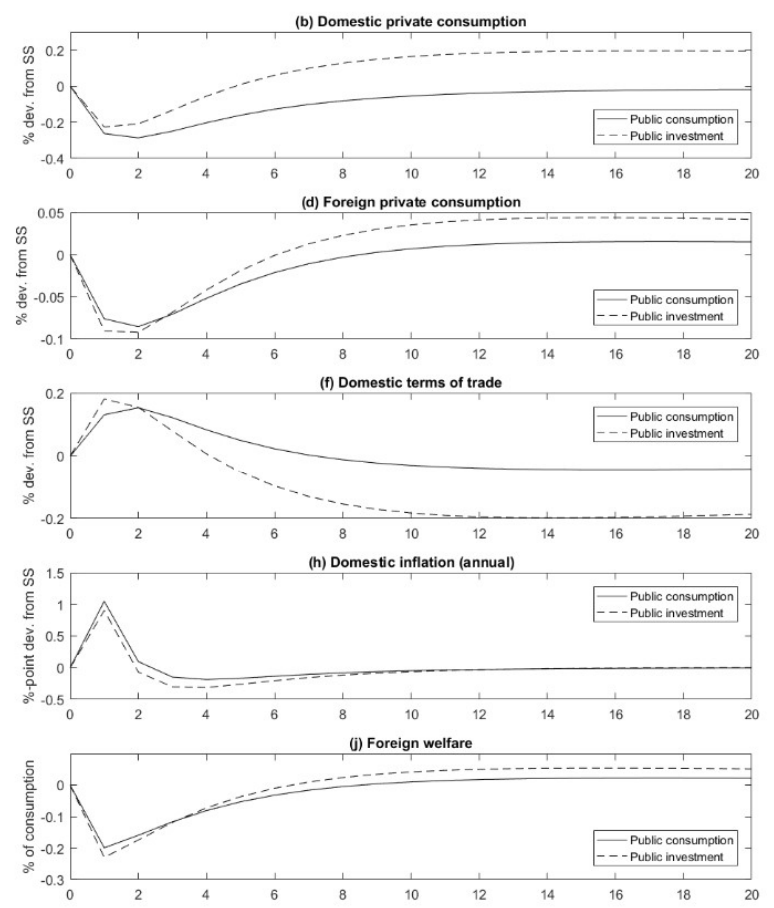

A public consumption shock increases domestic output. This is due to both to the increase in aggregate demand and to the wealth effect that pushes domestic households to work more when domestic taxes are increased. Table 2 shows that the cumulative output multipliers of public consumption over four and five years are 0.42-0.43. This is consistent with the empirical evidence provided by Gechert and Rannenberg (2014). In a meta-analysis of fiscal multipliers based on 98 empirical studies with more than 1800 observations, they find that the cumulative output multiplier of public consumption is 0.43 . Estimates for developing economies are rare. 
Kraay (2014) finds that the one-year spending multiplier is 0.4 in a group of 102 developing countries. Our result is fully consistent with this.

The domestic trade balance initially deteriorates because of the import component of the increased public spending. In the medium term, however, the fall in domestic consumption resulting from higher taxes, together with the improvement in the domestic terms of trade, imply an improvement in the domestic trade balance. Such hump-shaped behavior of the trade balance is consistent with the empirical evidence provided by Iwata (2013). The dynamics of other variables, including a short-lived increase in inflation due to the demand shock and a depreciation of the domestic real exchange rate in the medium term, are also consistent with Iwata (2013). We observe an increase in foreign output, due to both the increased demand in foreign goods stemming from the domestic fiscal shock and the short-term appreciation of the domestic exchange rate. However, given the substantial level of home bias in public spending, this spillover effect is weak.

Table 2. Output and Welfare Multipliers. $\mathrm{CM}=$ cumulative output multiplier, $\mathrm{PRs}=$ periods.

\begin{tabular}{|c|c|c|c|c|c|c|c|c|}
\hline & $\begin{array}{c}\mathrm{CM}, \\
4 \\
\text { PRs }\end{array}$ & $\begin{array}{c}\mathrm{CM}, \\
8\end{array}$ & $\begin{array}{c}\mathrm{CM}, \\
\text { PRs }\end{array}$ & $\begin{array}{c}\text { CM,16 } \\
\text { PRs }\end{array}$ & $\begin{array}{c}\mathrm{CM}, \\
20\end{array}$ & $\begin{array}{c}\text { NPV of } \\
\text { output } \\
\text { PRs }\end{array}$ & $\begin{array}{c}\text { Welfare } \\
\text { multiplier }\end{array}$ & $\begin{array}{c}\text { World } \\
\text { welfare } \\
\text { multiplier }\end{array}$ \\
\hline Consumption & 0.44 & 0.42 & 0.42 & 0.42 & 0.43 & 0.48 & -0.35 & -0.33 \\
\hline $\begin{array}{c}\text { Investment } \\
\text { (Advanced E) }\end{array}$ & 0.57 & 0.75 & 0.99 & 1.2 & 1.5 & 4.6 & 1.4 & 1.6 \\
\hline $\begin{array}{c}\text { Investment } \\
\text { (Developing } \\
\text { E) }\end{array}$ & 0.48 & 0.52 & 0.60 & 0.66 & 0.76 & 1.8 & 0.039 & 0.11 \\
\hline
\end{tabular}

Welfare effects are the main focus of our paper. Two contrasting effects on domestic welfare follow a domestic public spending shock. The increase in labor supply and the fall in private consumption due to higher taxes and the terms of trade imply a fall in domestic welfare. Public consumption yields utility, so an increase in public consumption increases welfare. Figure 1(i) shows that the first effect dominates, because the weight of public consumption in private utility is small. As shown in Table 2, the welfare multiplier for domestic households is -0.35 , meaning that they are willing to pay 0.35 dollars to avoid a one dollar rise in public consumption.

The first paper that analyzes the welfare multiplier of public consumption is Rendahl (2016). He analyzes fiscal policy in a liquidity trap using a model with hysteresis-like movements in unemployment. He finds that for a fiscal expansion of long duration the welfare multiplier is positive, while for a more temporary fiscal expansion it becomes negative. In particular, if the 
duration of the fiscal shock is short, the welfare multiplier is in the -0.4 to -0.2 range, which is very close to what we find. In our model, the welfare multiplier in general is smaller because the liquidity trap environment (Woodford 2011) and hysteresis (Engler and Tervala 2018) increases the effectiveness of fiscal policy.

Sims and Wolff (2018) argue that the sign of the welfare multiplier of public consumption depends heavily on the utility weight of public consumption, which is very poorly identified. They emphasize that the multipliers vary across states, which we cannot do since we use a linear approximation. However, they find that the welfare multiplier of public consumption in consumption equivalent terms is -0.17 around the non-stochastic steady state. Our welfare multiplier is more negative $(-0.35)$ than that of Sims and Wolff $(-0.17)$. A key reason is likely to be that they assume complementarity between private and public consumption. This increases the output multiplier of fiscal policy (Ganelli and Tervala 2009) and renders fiscal policy more beneficial. Sims and Wolff (2018) argue that the negative welfare multipliers imply that the initial amount of public consumption is higher than households would prefer. Our model would yield a positive output multiplier if public spending was set lower than the optimal level. For instance, if we set the weight of public consumption $(\vartheta)$ at 1.5 , the welfare would be 0.2 .

The welfare spillover effect on the foreign economy is positive. The improvement in the foreign terms of trade implies that foreign consumption rises by more than foreign output, which brings about a welfare improvement because it means that foreign households can increase their consumption with a proportionately lower increase in labor supply. The positive spillover effect implies that the world welfare multiplier is more negative $(-0.35)$ than that of the domestic economy $(-0.33)$.

\subsection{Public Investment}

\subsubsection{Advanced Economies}

In this section, we focus on the effects of a one percent of GDP increase in public investment in the case where the parameterization of the model matches the features of advanced economies. We discuss how the macroeconomic effects of our exercise on the main variables, especially the output multipliers, are substantially in line with the empirical evidence. This lends credibility to our welfare analysis, because it means that our study looks at the welfare impact of this policy in a reasonably realistic framework.

In the case of a public investment shock, we have both a temporary demand effect and a supplyside effect, because the productive capacity of firms increases with a higher capital stock. The second effect was missing in the previous case of a public consumption shock. Consequently, a public investment push increases medium-term output (Figure 1(a)), relative to the public 
consumption case. As can be seen in Table 2, the cumulative output multiplier increases with time, as a higher capital stock expands productive capacity. The time pattern of the output response is consistent with the empirical evidence of Iwata (2013), who shows that the shortterm effect of public investment is higher than the medium-term effect. Table 3 shows the cumulative output multipliers of the IMF's (2014) empirical study and our findings. Our output multipliers are almost identical to the empirical findings of the IMF (2014). Our results are also in line with the meta-analysis carried out by Gechert and Rannenberg (2014), who find that the cumulative fiscal multiplier of public investment is 1.4. The introduction of the inefficiency of public investment improves the model's ability to match the empirical estimates of the IMF (2014) on the cumulative output multipliers. They would exceed the empirical estimates without inefficiency.

Table 3. Output Multipliers. $\mathrm{CM}=$ cumulative output multiplier, $\mathrm{PRs}=$ periods.

\begin{tabular}{|c|c|c|c|c|c|}
\hline & CM, 4 PRs & CM, 8 PRs & CM, 12 PRs & CM,16 PRs & CM, 20 PRs \\
\hline IMF (2014) & 0.5 & 0.7 & 1 & 1.3 & 1.5 \\
\hline Our model & 0.6 & 0.8 & 1 & 1.2 & 1.5 \\
\hline
\end{tabular}

Coenen et al. (2012) study the output multipliers of public investment using the seven DSGE models of policy-making institutions. The average first-year multiplier for public investment spending is 1.5. In our model, the output multiplier of public investment is much smaller (0.6) and in line with the empirical evidence of the IMF (2014), according to which the first-year output multiplier is only 0.5 .

Table 2 shows that the NPV of the output multiplier (4.6) is much higher than the cumulative multipliers. This result arises mainly because, after four years, public investment spending has in essence returned to zero, but output remains high owing to the increase in the productive capacity generated by higher public capital. While very few papers have studied the long-term effects of public investment, our results point to public investment having a stronger output effect in the long term, compared with the existing literature. In the model by Bom and Ligthart (2014), the long-term output multiplier of a permanent increase in public investment is 2.3. The key reason for the difference is that we use a lower deprecation rate. However, our results are consistent with the conclusion by Bom and Ligthart (2013) that public capital is more productive in the long term than in the short term.

As Figure 1 shows, domestic consumption falls in the short term. This caused by the increase in the taxation needed to finance higher public investment. The public investment shock deteriorates the terms of trade in the short term, which tends to increase private consumption. However, the tax effect dominates and consumption falls in the short term. However, the tax effect fades away and, as in the empirical analysis by Iwata (2013), a public investment shock increases private consumption. In addition, an investment shock brings about an initial 
appreciation of the real exchange rate, followed by a depreciation, while the short-term interest rate (not shown in our graph) increases because of the reaction of the central bank following the increase in inflation, consistent with the empirical evidence offered by Iwata (2013).

The trade balance effect is in line with that observed in the case of a public consumption shock. Even though domestic private consumption goes down in the short term for the reason discussed above, we observe a deterioration in the overall domestic trade balance in the short term, due to higher public investment spending. In the medium term, the trade balance effect is reversed. This is consistent with Iwata's (2013) empirical evidence, who finds that the trade deficit first worsens and then improves following a public investment shock.

Overall, the macroeconomic effects of a public investment shock are in line with the empirical evidence. This lends credibility to our welfare results, which are the main innovation of this paper, to which we now turn. We see in Table 2 that our model points to substantial welfare gains from a public investment shock. The welfare multiplier of public investment is 1.4, meaning that domestic households would be willing to pay 1.4 dollars for a one dollar increase in domestic public investment. The intuition is that the gains in productivity linked to enhanced public capital imply an increase in private consumption without an identical increase in labor supply, which improves welfare.

Figure 1(j) shows that the welfare spillover effect is positive after some time. The improvement in the foreign terms of trade implies that foreign consumption rises by more than the foreign labor supply and output. The positive welfare spillover implies that the world welfare multiplier is larger (1.6) than the domestic welfare multiplier (1.4). Domestic and foreign households combined would be willing to pay 1.6 dollars for one dollar increase in domestic public investment.

Bom and Ligthart (2014) find that the welfare effect of a permanent increase in public investment is positive in the long term if the output elasticity of public capital exceeds the public investment to GDP ratio (3\%). Sims and Wolff (2018) examine the welfare multipliers of public investment using a closed-economy model in which parameters are set to match the features of the U.S. economy. Their welfare multiplier is positive in the benchmark parameterization, in which the output elasticity of public capital is 0.05 , while the multiplier is negative when it is 0.02 . Since these studies show that the welfare results are sensitive to the output elasticity of public capital, we conduct a sensitivity analysis to see how our results depend on it. The main innovation of the paper-relative to Bom and Ligthart (2014) and Sims and Wolff (2018) - is incomplete public investment efficiency and we analyze how the welfare multipliers also depend on the efficiency of public investment. 
The results of this sensitivity analysis are reported in Table 4. First, the higher the fraction of public investment spending that translates into the public capital stock, the higher the welfare multiplier. Second, the larger the output elasticity of public capital, the higher the welfare multiplier. High public capital productivity is not a sufficient condition for a positive welfare effect; the efficiency of public investment needs to be sufficiently high too. For countries with low public investment efficiency and productivity, an increase in public investment is not desirable from a welfare point of view. However, table 4 illustrates that-under plausible parameterization combinations for advanced economies - the welfare multiplier of public investment is positive.

Table 4. Domestic Welfare and Output Multipliers

(The cumulative output multiplier over 20 periods in parentheses).

\begin{tabular}{|c|c|c|c|c|}
\hline & $\zeta=0.57$ & $\zeta=0.73$ & $\zeta=0.87$ & $\zeta=1$ \\
\hline$\phi=0.02$ & $-0.26(0.6)$ & $-0.17(0.6)$ & $-0.10(0.7)$ & $-0.035(0.7)$ \\
\hline$\phi=0.03$ & $-0.11(0.7)$ & $0.015(0.7)$ & $0.13(0.8)$ & $0.23(0.9)$ \\
\hline$\phi=0.04$ & $0.039(0.8)$ & $0.21(0.9)$ & $0.35(0.9)$ & $0.49(1.0)$ \\
\hline$\phi=0.05$ & $0.19(0.8)$ & $0.40(1.0)$ & $0.57(1.1)$ & $0.76(1.2)$ \\
\hline$\phi=0.083$ & $0.69(1.1)$ & $1.0(1.3)$ & $1.36(1.5)$ & $1.66(1.6)$ \\
\hline$\phi=0.1$ & $0.94(1.3)$ & $1.4(1.5)$ & $1.8(1.7)$ & $2.1(1.9)$ \\
\hline
\end{tabular}

It is worth emphasizing that Bom and Ligthart (2014) and Sims and Wolff (2018) use the 10\% annual depreciation rate of public capital. In our model, the welfare multiplier is virtually to zero when $\phi=0.03, \delta=0.025$ and $\zeta=1$, a finding in line with Bom and Ligthart (2014). Sims and Wolff (2018) discover that the welfare multiplier of public investment is 0.33 around the non-stochastic steady state when $\phi=0.05$. In the comparable version $(\delta=0.025, \phi=$ 0.05 and $\zeta=1$ ), our multiplier is 0.21 . The open economy dimension of our model is the key here. In the closed-economy model of Sims and Wolff (2018), the (domestic) welfare multiplier takes into account all welfare effects. In our open economy model, a fraction of the welfare gains of public investment leaks abroad. A fiscal expansion increases the demand for foreign goods, increasing foreign income. In addition, the improvement in the foreign terms of trade means that foreign consumption increases by more than the foreign employment and output. In our model, the world welfare multiplier in the case of $\delta=0.025, \phi=0.05$ and $\zeta=$ 1 is 0.3 . Since this finding is consistent with Sims and Wolff (2018), their welfare multipliers may overestimate the welfare gains of public investment in the domestic economy for two reasons. First, they assume full public investment efficiency. Second, their multipliers do not take into account that a fraction of the welfare gains of public investment leaks abroad. On the other hand, Sims and Wolff's (2018) welfare multipliers may underestimate the welfare benefits of public investment because they set the productivity of public capital at $5 \%$, whereas the meta-analysis by Bom and Ligthart (2013) shows that it is roughly $8 \%$. In addition, they set the annual depreciation rate at $10 \%$, whereas according to the IMF (2015) it is $5 \%$. 


\subsubsection{Developing Economies}

Next, we examine the effects of a one percent of GDP increase in public investment in the case where the parameterization of the model matches the features of developing economies. As mentioned, we set public investment efficiency at 0.57 for developing economies. What is the right value of the productivity of public investment in developing economies? The metaanalysis of Bom and Ligthart (2013) uses 68 studies that estimate the productivity of public investment, but only one (Dessus and Herrera 2000) focuses on developing countries. According to Bom and Ligthart (2013), the relative output elasticity of public capital in Dessus and Herrera (2000) is $56 \%$ of that of the average of all estimates. Since Bom and Ligthart (2013) find an output elasticity of public capital of 0.083 , it may be almost 0.05 in developing economies. However, this value would imply that we could not match the empirically observed output multiplier of public investment in developing countries. If we set the productivity of public capital at 0.03 , we can match them, as shown below. Our choice for the output elasticity of public capital in developing countries is a compromise and we set it at 0.04 .

The IMF (2014) highlights that data limitation is a serious issue in the empirical estimation of the macroeconomic effects of public investment in developing economies. First, the IMF (2014) estimates a fiscal policy rule for public investment to obtain a series of exogenous shocks to public investment for a sample of 128 emerging and developing economies. Using this methodology, the cumulative output multiplier is 0.25 in the first year and 0.5 in the fifth year. Second, the IMF (2014) uses public investment implemented by official loan disbursement in a sample of 95 emerging and developing economies. Using this methodology, the cumulative output multiplier is 0.5 in the first year and 0.9 in the fifth year. The effects on output are much smaller, but more precisely estimated, using the first method. We believe that the averages of these estimates are the best ones and we set the productivity of public capital such that the output multiplier is close to 0.4 after one year and 0.7 after five years.

Figure 2 shows the effects of a rise in domestic public investment spending. The dashed (solid) lines show the effects in developing (advanced) economies. Table 2 shows that the first-year output multiplier is only 0.5 , which is almost identical to the average IMF findings. The output multiplier is 0.76 in the fifth year, which is almost identical to the average IMF estimate (0.7). This gives credibility to our analysis since we analyze the effects of public investment under a realistic parameterization. Introducing inefficiency enhances the model's ability to match the empirically observed low output multipliers. Without it, the low output multipliers could not be matched without assuming an implausible low productivity of public capital (2\%).

Figure 2 shows that while the main variables move qualitatively pretty much the same way in developing economies, quantitative differences in domestic output and private consumption are substantial. Less public investment efficiency implies a smaller increase in public capital. 
In addition, low output elasticity of public capital means a much smaller output effect on developing economies. The increase in the taxation needed to finance higher public investment is identical in developing and advanced economies. Thus the tax effect dominates much longer and a medium-term rise in private consumption is very much smaller than in advanced economies.

Figure 2. Effects of Public Investment.
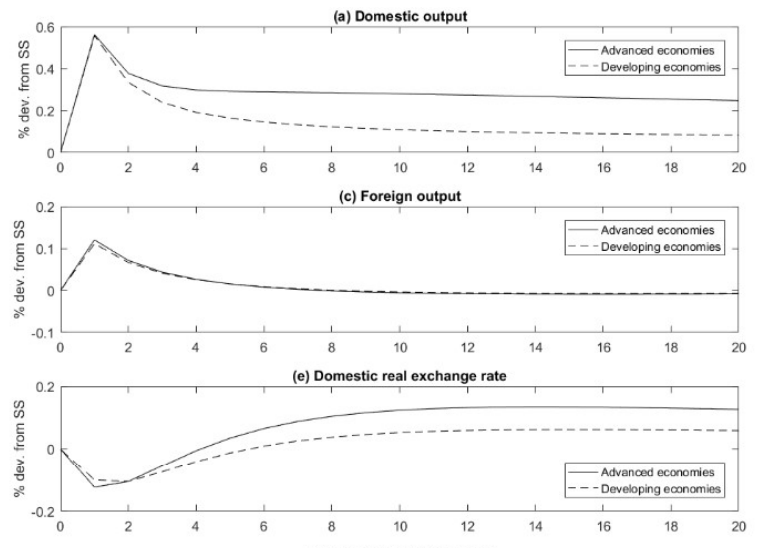

(g) Domestic trade balance
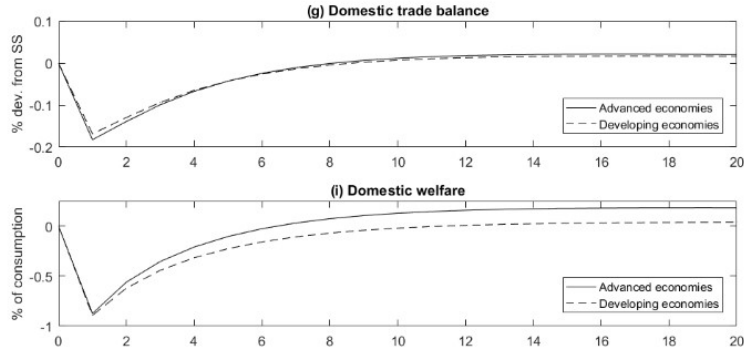
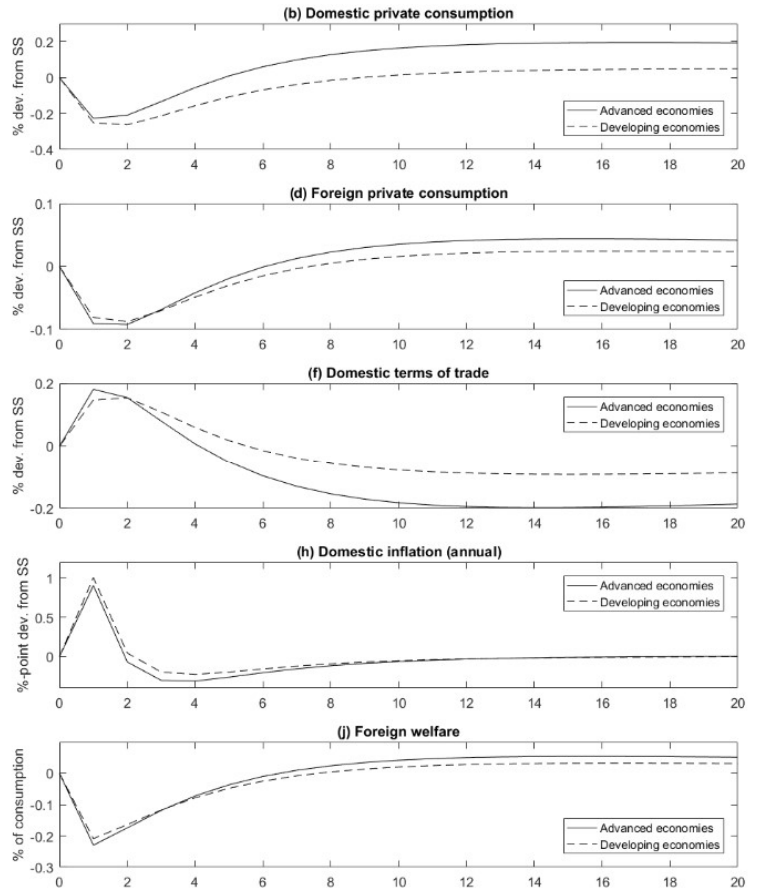

Table 2 shows that the welfare multiplier of public investment in developing economies is 0.039 . Households are thus willing to pay only 0.039 dollars for a one dollar increase in public investment. The gains in productivity caused by enhanced public capital imply an increase in private consumption in the medium term. A public investment shock causes an increase in the labor supply, which reduces welfare. The welfare gain caused by a modest increase in private consumption offsets the welfare loss caused by an increase in the labor supply.

As discussed earlier, low public investment efficiency and productivity imply a negative welfare multiplier. Table 4 shows that if the productivity of public capital is 0.03 , the welfare multiplier is -0.11 , because the welfare loss caused by a rise in the labor supply more than offsets the welfare gain caused by a rise in private consumption. In this case, the output multiplier after five years (0.7) is fully consistent with the average IMF estimate (0.7). In our view, it is fair to say that under plausible parameter values for developing economies, the welfare multiplier is may be just above zero or even negative. 
Table 4 shows that when $\phi=0.04$ and public investment efficiency is 0.73 , which is the IMF's (2014) estimate for emerging economies, the welfare multiplier is 0.21 . However, the cumulative output multiplier over 20 periods is higher (0.9) than the average IMF estimate (0.7). If the productivity of public capital is 0.083 , as in advanced economies, the cumulative output multiplier over 20 periods is 1.1 , which is higher than the average IMF estimate (0.7). In addition, the IMF's (2014) estimate, using the fiscal policy rule methodology, was only 0.5 . This suggests that the productivity of public capital in developing economies cannot be as high as 0.083 in general. However, the public investment implemented by official loan disbursement methodology implies than the effects on output are higher but rather imprecisely estimated. The IMF $(2014,101)$ argues that this "could simply reflect the wide variety of experiences with public investment in developing economies." This may be due to huge differences in the efficiency and productivity of public investment. Some developing economies may have used public investment implemented by official loan disbursement so wisely that they have yielded nice welfare benefits.

Table 4 suggests that the lower productivity of public capital is the most important factor for the lower welfare multiplier of public investment for developing countries. In the case where $\phi=0.083$, the welfare multiplier of public investment drops from 1.36 to 0.69 , when the efficiency of public investment is reduced from the baseline value for advanced economies (0.87) to the baseline value for developing economies (0.57). In the case where $\zeta=0.87$, the welfare multiplier drops to 0.35 , when the productivity of public capital is reduced from the baseline for advanced economies $(8.3 \%)$ to the baseline for developing economies (4\%).

The IMF (2014) analyzes briefly the implications of low public investment efficiency in developing economies. This shows that in countries with high (low) investment efficiency, a deficit financed rise in public investment leads to significant (weak) growth effects and a decline (an increase) in the public debt to GDP ratio. It does not, however, analyze the output or welfare multipliers of fiscal policy. It is worth observing that it sets the output elasticity of public capital at $25 \%$. In our view, the choice value of 0.25 is implausible. If the productivity of public capital is set at $25 \%$, the cumulative output multiplier of public investments over 20 periods is 2.5 in our model. This is more than three times higher than the average of the empirical estimates of the IMF (2014).

The policy implications of public investment efficiency are disputed. On the one hand, low public investment efficiency has been seen as the key problem. Pritchett (2000) argues that in developing countries low efficiency is of first-order importance because public investment creates little capital and even where public capital could make a potentially large contribution to production, public investment spending has a low impact on economic performance. The IMF (2014) argues that if the efficiency of public investment is low, public investment leads 
to very limited output gains. Thus the key priority in low efficiency countries should be to raise public investment efficiency. On the other hand, Berg et al. (2019) argue that the efficiency and scarcity of public capital are inversely related across countries and that - in growth theory - the productivity of public capital is higher in low-efficiency countries. They claim that both the efficiency and productivity of public investment need to be considered together in evaluating the consequences of a rise in public investment. In their view, recommendations against a public investment push in inefficient countries do not make sense because lowefficiency countries reap at least an identical output gain from public investment.

Our paper offers a novel view on this debate. First, the empirical evidence offered by the IMF (2014) shows that the output effect of public investment in advanced economies (1.5) is double that of developing economies (0.7). Second, the empirical evidence in the IMF (2015) shows that the efficiency of public investment is much higher in advanced economies than developing economies. In our DSGE model, these two empirical observations are impossible to reconcile without assuming smaller public capital productivity in developing countries. In practice, public investment efficiency and productivity are both likely to be lower in developing countries than in advanced economies; public investment efficiency and productivity may be inversely related across developing economies. However, the empirically observed weak output effects of public investment suggest that both the efficiency and productivity may be so low in developing economies that the welfare multiplier of public investment in developing economies is just above zero. Developing economies should be to raise both the efficiency and productivity of public investment.

\subsection{Sensitivity Analysis}

Table 5 shows the sensitivity of the main results to changes in parameter values. Row 1 replicates the baseline result for developing economies. The second column shows the parameters used in the sensitivity analysis and the baseline parameterization is shown in parentheses.

In row 2 , the depreciation rate is doubled from the baseline value of 0.0125 to 0.025 , which implies that the annual depreciation rate increases to $10 \%$. The higher the depreciation rate, the smaller the supply-side effect of public investment in the medium and long term. Table 5 shows that the welfare multiplier drops to -0.21 . The main policy message is that public investment decisions should take into account the life span of public capital.

The welfare multipliers may be sensitive to the value of within-country substitutability, because it affects the level of initial output and employment (equation 13). Row 3 (4) of Table 5 shows that when within-country substitutability is 6 (21), implying a 20 (5) percent price markup, the domestic welfare multiplier is 0.061 (0.026). Hence, welfare multipliers are not sensitive to changes in it. 
The effects of fiscal policy in DSGE models are sometimes sensitive to the Frisch elasticity of labor supply. In row 5 , it is reduced from 0.7 to 0.5 , while in row 7 it is increased to 2 . The higher the Frisch elasticity, the stronger the output effect of an investment shock. However, the welfare multipliers are robust to changes in it.

Table 5. Robustness Checks for Developing Economies.

\begin{tabular}{|c|c|c|c|}
\hline Row & Parameter & $\begin{array}{c}\text { Cumulative output multiplier, 20 } \\
\text { periods }\end{array}$ & $\begin{array}{c}\text { Welfare } \\
\text { multiplier }\end{array}$ \\
\hline 1 & Baseline & 0.8 & 0.039 \\
\hline 2 & $\delta=0.025(\delta=0.0125)$ & 0.7 & -0.21 \\
\hline 3 & $\theta=6(\theta=11)$ & 0.8 & 0.061 \\
\hline 4 & $\theta=21(\theta=11)$ & 0.8 & 0.026 \\
\hline 5 & $v=0.5(v=0.7)$ & 0.7 & 0.048 \\
\hline 6 & $v=2(v=0.7)$ & 1.0 & 0.010 \\
\hline 7 & $\alpha=1.44(\alpha=1.68)$ & 0.7 & -0.027 \\
\hline 8 & $\rho=3(\rho=1.5)$ & 0.8 & 0.083 \\
\hline 9 & $\gamma=0.0(\gamma=0.5)$ & 0.7 & 0.054 \\
\hline 10 & $\gamma=0.75(\gamma=0.5)$ & 0.8 & 0.029 \\
\hline 11 & $\rho^{I}=0.93(0.75)$ & 0.6 & 0.043 \\
\hline 12 & $C_{0} / y_{0}=0.8\left(C_{0} / y_{0}=\right.$ & 0.8 & 0.042 \\
\hline 13 & $n=0.01(\mathrm{n}=0.5)$ & & 0.049 \\
\hline
\end{tabular}

The open economy dimension is a key difference from Sims and Wolff (2018) and in our model a fraction of the welfare gain of public investment leaks abroad. The international welfare leakage depends on the degree of openness and cross-country substitutability. In row 7 , the home bias parameters in both countries are changed such that the import to GDP ratio is increased from $16 \%$ to $28 \%$, which is the world average (World Bank 2018). The more open the economy is, the smaller the welfare multiplier is. Actually, the welfare multiplier turns negative. However, the quantitative change is small. Cross-country substitutability governs how much changes in the international price ratio affect the relative demand for domestic and foreign goods. It also influences the size of the terms-of-trade change. This is relevant because the deterioration of the domestic terms of trade is the main reason why a substantial fraction of welfare effects leak abroad. In row 8, cross-country substitutability is doubled from 1.5 to 3. We observe a small increase in the welfare multiplier. The international dimension is an important feature of the model, but the international welfare leakage is robust to small changes in the degree of openness and cross-country substitutability. 
In row 9 , the probability of not adjusting prices is reduced from 0.5 to 0 , while in row 10 it is increased to 0.75 . The more rigid the price, the stronger the fiscal policy demand effect, which drives up output in the short term. However, the welfare multiplier of fiscal policy is almost exclusively determined by the supply-side effect and price rigidities hardly change it. In row 11, the persistence of the shock is increased from 0.75 to 0.93 , the value used by Sims and Wolff (2018). While the absolute welfare effect of fiscal policy is obviously affected by the duration of the shock, the welfare multiplier is - in practice - unaffected, because it measures the welfare effect of a one dollar change in investment.

The welfare multiplier may depend on the initial level of public investment. In our model, the initial level of employment (equation 13) affects the welfare multiplier (see equation 16). Since the public capital stock increases the real wage, households substitute leisure for labor. The income effect increases both consumption and leisure. The log utility for consumption implies that income and substitution effects for the labor supply cancel each other out in the steady state. The key is not only level of public investment and but also the level of public consumption as the initial level of employment depends on the output to private consumption ratio. Holding the proportion of public consumption spending constant while reducing the initial level of public investment by one percentage point relative to GDP implies that the welfare multiplier is a slightly higher. However, the welfare multiplier is virtually independent of the initial level of public investment, holding the productivity of public capital constant. We should keep in mind that decreasing returns to capital implies that an increase public in capital leads to a smaller increase in output as the level of public capital increases. This is taken into account in the model, as the welfare multiplier is very sensitive to the productivity of public capital, which should depend on the initial level of public capital.

In row 14, we analyze the small-country case where the relative size of the home country is $1 \%$ of the world economy. At the same time, we change the home bias parameter $\alpha$ such that the domestic import to GDP ratio remains at $16 \%$ and we adjust the foreign import to GDP ratio such that the per-capita level of output is identical across countries. We observe a very small change in the welfare multiplier, because even small countries affect their terms of trade under imperfect competition. Therefore, country size has a small effect on the welfare multiplier.

In summary, our results suggest public investment increases welfare provided that public investment efficiency is sufficiently high, the lifespan of public capital is sufficiently long, and the productivity of public capital is sufficiently high. The model, however, lacks elements that may play an important role in the welfare implications of public investment. First, the fact that the relationship between private and public investment is disputed does not imply that private capital does not matter for the welfare effects of public investment. If there were a crowding out effect on private investment, the welfare multiplier of public investments would be smaller. 
Second, the absence of distortionary taxes implies that we ignore a channel of fiscal policy, tax distortions which would reduce the welfare multiplier of public investment. However, the output multipliers of our model are in line with the empirical evidence which lends credibility to our analysis.

\section{CONCLUSIONS}

Empirical studies support the view that there are significant inefficiencies in public investment and this has not been taken into account in DSGE macroeconomics. We analyze the consequences of the incomplete efficiency of public investment for the output and welfare multiplier of fiscal policy in a DSGE model. We conclude that the welfare multiplier of public investment is positive only if the efficiency of public investment is sufficiently high, the depreciation rate of public capital is sufficiently low and the output elasticity of public capital is sufficiently high. In advanced economies, a public investment push is much more attractive than previously thought. Our welfare multiplier (1.4) is roughly four times that of Sims and Wolff (2018). Good public investment management, however, is needed to ensure a positive welfare multiplier of public investment.

The welfare multiplier of public investment may be just above zero in developing economies and they should improve public investment management to enhance public investment efficiency and the productivity of public capital. The GDP of low and middle income countries was 29236 billion U.S. dollars in 2017 (World Bank 2018). Let us assume that their public investment to GDP ratio was 9\%, which is the IMF's (2014) estimate for emerging and developing countries at the beginning of the 2010s. In our model, the output multiplier at the 10 -year horizon for a quasi-permanent fiscal shock is roughly 0.2 units higher where public investment efficiency is 0.73 rather than the baseline value of 0.57 . If all low and middle income countries improve the efficiency of public investment to the level of emerging economies, this will — holding the level of public investment constant - boost the annual GDP of low and middle income countries by 523 billion U.S. dollars in ten years. The IMF (2015) finds that improvements in public investment management can significantly enhance public investment efficiency and productivity and argues that governments should strengthen institutions that are responsible for the planning, allocation, and implementation of public investment. Our calculation shows that potential gains from an improvement in public investment efficiency alone may be considerable for developing economies.

Views on the implications of public investment inefficiency for economic policy diverge. According to Pritchett (2000) and the IMF (2014), low efficiency is first-order importance in developing economies, because public investment spending creates little capital and consequently the output effect is small. In this view, the key priority is to raise efficiency. Berg et al. (2019), on the other hand, say that the productivity of public capital must be higher in low-efficiency countries, because in growth theory they are inversely related. They conclude 
that the output effect in low-efficiency countries is at least as high as in high-efficiency countries. In this view, low efficiency is not even problematic. Our paper offers a fresh view. First, the IMF (2014) discovers that the output multiplier in developing economies (0.7) is roughly half that of advanced economies (1.5). Second, the IMF (2015) shows that efficiency is lower in developing economies. The empirical findings cannot be reconciled without assuming a higher productivity of public capital in advanced economies. In developing economies, efficiency and productivity may be both so low that the welfare multiplier of public investment is just above zero (0.039). If developing economies raised efficiency (productivity) to the level of advanced economics, the welfare multiplier would increase to $0.35(0.69)$. We conclude than developing economies should improve not only the efficiency of public investment but also the productivity of public capital. Actually, the potential welfare gains of the latter may be higher. 


\section{REFERENCES}

Agenor, P-R. 2010. A theory of infrastructure-led development. Journal of Economic Dynamics \& Control 34, 932-950.

Basu, P. and R. Kollman 2013, Productive government purchases and the real exchange rate. The Manchester School 81, 461-469.

Baxter, M. and R. G. King, 1993. Fiscal policy in general equilibrium. American Economic Review 83, 315-334.

Berg, A, E.F Buffie, C. Pattillo, R. Portillo, A. F. Presbitero and L-F. Zanna 2019. Some misconceptions about public investment efficiency and growth. Economica 83, 409430 .

Bergin, P. R, 2006. How well can the new open economy macroeconomics explain the exchange rate and current account? Journal of International Money and Finance 25, $675-701$.

Bils, M. and P. Klenow 2004. Some evidence on the importance of sticky prices. Journal of Political Economy 112, 947-985.

Bom, P.R.D and J. E. Ligthart R, 2013. What have we learned from three decades of research on the productivity of public capital? Journal of Economic Surveys 28, 889-916.

Bom, P.R.D and J. E. Ligthart, 2014. Public infrastructure investment, output dynamics, and balanced budget fiscal rules. Journal of Economic Dynamics \& Control 40, 334-354.

Caselli, F. 2005. Accounting for Cross-Country Income Differences. In Handbook of Economic Growth vol 1. Philippe Aghion \& Steven Durlauf(eds.), pages 679-741.

Calvo, G. A., 1983. Staggered prices in a utility maximizing framework. Journal of Monetary Economics 12, 383-398.

Clarida, Richard, Jordi Galí, and Mark Gertler, 2000. Monetary policy rules and macroeconomic stability: Evidence and some theory. Quarterly Journal of Economics, Vol. 115, No. 1, pp. 147-180.

Chetty, R., A. Guren, D. Manoli and A. Weber, 2013. Does indivisible labor explain the difference between micro and macro elasticities? A meta-analysis of extensive margin elasticities. NBER Macroeconomics Annual 2012 27, 1-56. 
Coenen, G., C. J. Erceg, C. Freedman, D. Furceri, M. Kumhof, R. Lalonde, D. Laxton, J. Lindé, A. Mourougane, D. Muir, S. Mursula, C. de Resende, J. Roberts, W. Roeger, S. Snudden, M. Trabandt, and J. In't Veld 2012. Effects of fiscal stimulus in structural models. American Economic Journal: Macroeconomics 4, 22-68.

Coenen, G., Straub, R. and M.Trabandt 2013. Gauging the effects of fiscal stimulus packages in the euro area. Journal of Economic Dynamics \& Control 37, 367-386.

Dabla-Norris, E., J. Brumby, A. Kyobe, Z, Mills and C. Papageorgiou 2012. Investing in public investment: An index of public investment efficiency. Journal of Economic Growth 17, $235-266$.

Dessus, S. and R. Herrera 2000. Public capital and growth revisited: A panel data assessment. Economic Development and Cultural Change 48, 407-418.

Dong, W. 2012. The role of expenditure switching in the global imbalance adjustment. Journal of International Economics 86, 237-251.

Engler. P. and J. Tervala 2018. Hysteresis and fiscal policy. Journal of Economic Dynamics \& Control 93, 39-53.

Ganelli, G. and J. Tervala 2009. Can government spending increase private consumption? The role of complementarity. Economics Letters 103, 5-7.

Gechert, S. and A. Rannenberg 2014. Are fiscal multipliers regime-dependent? A meta regression analysis, IMK Working Paper 139.

Gupta, S., A. Kangur, C. Papageorgiou and A. Wane 2014, Efficiency-Adjusted Public Capital and Growth. World Development 57, 164-178.

IMF 2014. World economic outlook: Legacies, clouds, uncertainties. IMF, Washington, DC.

IMF 2015. Making public investment more efficient. IMF, Washington, DC.

Iwata, Y, 2013. Two fiscal policy puzzles revisited: New evidence and an explanation. Journal of International Money and Finance 33, 188-207.

Justiniano, A., Primiceri, G. and A. Tambalotti 2011. Investment shocks and the relative price of investment. Review of Economic Dynamics 14, 101-121. 
Kamps, C., 2006. New estimates of government net capital stocks for 22 OECD countries, 1960-2001. IMF Staff Papers, 53, 120-150.

Keane, M. and R. Rogersson, 2012. Micro and macro labor supply elasticities: A reassessment of conventional wisdom. Journal of Economic Literature 50, 464-476.

Klein, P., 2000. Using the generalized Schur form to solve a multivariate linear rational expectations model. Journal of Economic Dynamics \& Control 24, 1405-1223.

Kraay, A. 2014. Government spending multipliers in developing countries: Evidence from lending by official creditors. American Economic Journal: Macroeconomics 6, 170 208.

Mankiw, G. and M. Weinzierl 2011. An exploration of optimal stabilization policy. Brookings Papers on Economic Activity 42, 209-272.

McCallum, B., 2001. Software for RE analysis. Computer software available at https://dge.repec.org/codes/mccallum/.

Obstfeld, M. and K. Rogoff 1995. The intertemporal approach to the current account. In G. Grossman and K. Rogoff (eds.) Handbook of International Economics. North-Holland Publishing Company, Amsterdam.

Pritchett, L. 2000. The tyranny of concepts: CUDIE (cumulated, depreciated, investment effort) is not capital. Journal of Economic Growth 5, 361-384.

Rendahl, P. 2016. Fiscal policy in an unemployment crisis. Review of Economic Studies 83, 1189-1224.

Rioja, K. K- 1999. Productiveness and welfare implications of public infrastructure: A dynamic two-sector general equilibrium analysis. Journal of Development Economics $58,387-404$.

Schmitt-Grohe, S. and M. Uribe, 2003. Closing small open economy models. Journal of International Economics 61, 163-185.

Schmitt-Grohe, S. and M. Uribe, 2007. Optimal simple and implementable monetary and fiscal rules. Journal of Monetary Economics 54, 1702-1725. 
Sims, E. and J. Wolff, 2018. The output and welfare effects of government spending shocks over the business cycle. International Economic Review 59, 1403-1435.

Song, Z., K. Storesletten and F. Zilibotti 2012. Rotten parents and disciplined children: A politico-economic theory of public expenditure and debt. Econometrica 80, 27852803.

Taylor, J. B. 1993. Discretion versus policy rules in practice. Carnegie-Rochester Conference Series on Public Policy 39, 195-214.

Uhlig, H., 2010. Some fiscal calculus. American Economic Review 100, 30-34.

Woodford, M. 2011. Simple analytics of the government expenditure multiplier. American Economic Journal: Macroeconomics 3, 1-35.

World Bank, 2018. Data available online at http://data.worldbank.org/ (accessed 16.10.2018). 